\begin{tabular}{|c|c|}
\hline$x_{10}$ & Malaysian Journal of Social Sciences and Humanities (MJSSH) \\
\hline Malaysian Journal of & Volume 6, Issue 2, February 2021 \\
\hline (MJ-SSH) & e-ISSN : 2504-8562 \\
\hline & $\begin{array}{l}\text { Journal home page: } \\
\text { www.msocialsciences.com }\end{array}$ \\
\hline
\end{tabular}

\title{
Literasi Media Sosial Pelajar Politeknik Terhadap Aspirasi Kerjaya Keusahawanan Digital
}

\author{
Nurfarahin Khalil ${ }^{1}$, Nor Aishah Buang ${ }^{1}$, Norasmah Othman ${ }^{1}$ \\ ${ }^{1}$ Fakulti Pendidikan, Universiti Kebangsaan Malaysia (UKM) \\ Correspondence: Nurfarahin Khalil (p99604@siswa.ukm.edu.my)
}

\begin{abstract}
Abstrak
Kajian ini dijalankan bertujuan mengenal pasti tahap literasi media sosial dalam kalangan pelajar Politeknik Sultan Salahuddin Abdul Aziz Shah (PSA) terhadap pemilihan kerjaya keusahawanan digital. Responden kajian terdiri daripada pelajar semester akhir di Jabatan Perdagangan. Kajian ini berbentuk tinjauan dengan menggunakan kaedah kuantitatif. Data dikumpulkan dengan menggunakan instrumen borang soal selidik serta diedarkan menggunakan Google form. Data dianalisis menggunakan perisian Statistical Package Social Science (SPSS) versi 26. Item kajian menggunakan Skala Likert 5 bagi menerangkan item soal selidik. Data kajian yang diperoleh dianalisis menggunakan statistik deskriptif yang melibatkan nilai min dan sisihan piawai. Hubungan antara literasi media sosial terhadap pemilihan kerjaya keusahawanan digital diuji menggunakan ujian Korelasi Pearson. Dapatan kajian ini menunjukkan skor min tahap literasi media sosial adalah tahap sederhana tinggi. Berdasarkan hasil kajian, terdapat beberapa implikasi penting dalam menekankan lebih banyak aktiviti pengajaran dan pembelajaran berasaskan media sosial untuk menggalakkan pelajar PSA memilih bidang keusahawanan digital setelah tamat pengajian. Secara keseluruhan, terdapat hubungan yang signifikan antara literasi media sosial pelajar PSA terhadap pemilihan kerjaya keusahawanan digital. Seterusnya, kajian ini diharapkan dapat membantu pensyarah untuk merancang strategi dan pendekatan aktiviti kepada pelajar kearah pemilihan kerjaya keusahawanan digital pada masa hadapan.
\end{abstract}

Kata kunci: literasi media sosial, keusahawanan digital, pemilihan kerjaya

\section{Polytechnic Student Social Media Literacy Towards Digital Entrepreneurship Career Aspirations}

\begin{abstract}
This study was carried out to determine the level of social media literacy among students of Sultan Salahuddin Abdul Aziz Shah Polytechnic (PSA) on the career option of Digital Entrepreneurship career. The study respondents of the consisted of the Department of Commerce's final semester students. This research is conducted using quantitative methods in the form of a survey. Using the questionnaire organization, data was collected and distributed using Google form. The data was analyzed using Statistical Package Social Science (SPSS) version 26. To define the questionnaire items, the study items used Likert Scale 5. Descriptive statistics involving mean values and standard deviations were used to interpret study results. The Pearson Correlation Test explores the relationship between social media
\end{abstract}


literacy and career choices for digital entrepreneurship. The results of this study indicate that the average level of social media literacy is relatively high. On the basis of the study findings, there are some major implications for emphasizing more social media-based teaching and learning activities to enable PSA students to choose the area of digital entrepreneurship after graduation. Overall, there is a major connection between PSA students' social media literacy with digital career choice for entrepreneurship. In addition, this study is intended to help lecturers prepare student plans and activities for the selection of possible digital entrepreneurship careers.

Keywords: social media literacy, digital entrepreneurship, career choice

\section{Pengenalan}

Kajian Perniagaan atas talian merupakan aktiviti yang menjadi fenomena di seluruh negara. Kehadiran Pandemik Coronavirus (COVID-19) telah memberi impak positif kepada sektor perniagaan atas talian atau e-dagang (Utusan, 2020). Pandemik COVID-19 memerlukan organisasi perniagaan berfikir secara kritis dari proses perniagaan dan penggunaan media sosial untuk mengekalkan operasi mengikut prosedur baru menggunakan teknologi mudah alih, interaksi sosial dan strategi daripada krisis semasa (Dwivedi et al. 2020). Laporan Abrar (2020) Amazon telah mencatat keuntungan 345 juta USD dalam perniagaan antarabangsa, disebabkan peningkatan jumlah pembeli atas talian dalam tempoh Perintah Kawalan Pergerakan (PKP) (Business Standard, 2020). Menurut kajian Vase.ai (2020) 60\% penduduk Malaysia aktif dalam pembelian secara atas talian sepanjang tempoh PKP. Perniagaan digital melalui media sosial merupakan perkhidmatan penting bukan sahaja di Malaysia tetapi negara-negara Asia Tenggara seperti Singapura, Indonesia dan Filipina (Vase.ai, 2020). Di United Kingdom penyebaran maklumat melalui media sosial menggalakkan pembeli membeli keperluan untuk tinggal di rumah dalam tempoh yang tidak pasti sepanjang pandemik COVID-19 (Naeem, 2021).

Laporan Digital Global Overview (2020) pengguna internet dunia melebihi daripada 4.5 bilion orang serta separuh penduduk dunia telah menggunakan media sosial. Media sosial mempengaruhi individu dalam menceburi bidang keusahawanan (Wei et al., 2020). Pertumbuhan teknologi serta aplikasi media sosial telah mewujudkan peluang besar kepada pelajar dan bakal usahawan untuk memasuki dunia keusahawanan teknologi dengan kos yang rendah. Menurut Bakar et al. (2016) wujud peluang dalam bidang keusahawanan adalah dengan penerokaan perubahan teknologi. Faradillah et al. (2019) kemunculan media sosial seperti Twitter, Instagram dan Facebook yang digunakan oleh sebahagian besar pengguna internet bagi merancakkan perniagaan secara atas talian. Di Malaysia, pengguna internet juga meningkat terutama bagi golongan berumur 18 sehingga 34 tahun yang merupakan pengguna aktif media sosial (Statista, 2020). Kini, pemilihan kerjaya perniagaan atas talian mendapat perhatian dalam kalangan pengguna internet dan khususnya golongan pelajar (Nurulhayah et al., 2018). Pelajar bergantung kepada internet untuk memenuhi keperluan sosial serta memahami persekitaran sosial bertujuan berkongsi minat, meluahkan perasaan dan mendapatkan maklumat semasa (Normah et al., 2013). Menurut Ahmad Fkrudin dan Wan Norina (2015) pengaruh media sosial memberi kesan positif terhadap pemilihan pelajar untuk melakukan perkara yang berfaedah mahupun sebaliknya.

Kementerian Pembangunan Usahawan (2019) menggalakkan pelajar untuk membangunkan bidang keusahawanan dengan penggunaan teknologi bertujuan melahirkan usahawan yang lebih kompetitif. Teknologi membantu golongan pelajar tahun akhir dalam mencipta peluang dalam perniagaan berasaskan perusahaan atas talian (Finkle n.d.). Menurut Siti Masayu (2016) dalam usaha memperkasakan golongan pelajar, penggunaan teknologi dalam aktiviti bidang keusahawanan mampu merancakkan ekonomi negara. Pelajar universiti awam mahupun swasta mampu memanfaatkan peluang yang wujud, hal ini kerana mereka sentiasa meneroka ilmu teknologi dalam bidang keusahawanan (Faizal, 2019). Kerancakan Revolusi Industri 4.0 yang semakin memuncak di seluruh dunia menjadikan individu untuk bertindak lebih pantas seiring dengan transformasi dalam pembangunan sistem serta produk berteknologi (World Economic Forum, 2016). 
Golongan pelajar merupakan golongan yang cepat menyesuaikan diri dengan perubahan teknologi serta memberi kelebihan rangkaian sosial, keyakinan serta peluang pelajar untuk mengintegrasikan produktiviti dalam pekerjaan (Picatoste et al., 2018).

Di Malaysia, kehadiran pandemik COVID-19 memberi kesan kepada dunia pekerjaan terutamanya golongan pelajar. Oleh yang demikian, pelajar universiti mahupun kolej sering dikaitkan dengan isu pengangguran. Laporan Jabatan Perangkaan Malaysia kadar pengangguran di Malaysia meningkat pada 5.1 peratus pada suku tahun kedua 2020. Data ini menunjukkan bahawa penganggur siswazah merupakan penyumbang utama dengan jumlah pengangguran sebanyak 29.3\% lebih daripada separuh jumlah keseluruhan menganggur. Menurut laporan statistik pengangguran yang dikeluarkan oleh laporan statistik (2019) menunjukkan jumlah pelajar politeknik yang masih menganggur adalah sebanyak 3.9\% (2239 orang) (Laporan Pengesahan Graduan, 2018). Kadar graduan 2018 belum bekerja mengikut bidang pengajian menunjukkan bahawa sains sosial sebanyak $21.2 \%$ lebih tinggi berbanding dengan sains tulen sebanyak 19.7\%. Justeru, Pelan Tindakan Keusahawanan Institusi Pendidikan Tinggi 2021-2025 yang dihasilkan oleh Kementerian Pendidikan Tinggi (KPT) bertujuan untuk meluaskan perniagaan digital dalam menyokong golongan pelajar untuk membuka perniagaan sendiri. Selain itu, KPT juga menyasarkan sebanyak $5 \%$ pelajar yang bergraduasi untuk mencipta peluang pekerjaan sendiri dan menjadikan aktiviti bidang keusahawanan sebagai kerjaya pilihan di masa akan datang (Berita Harian, 2020)

\section{Sorotan Literatur}

\section{Keusahawanan Digital}

Keusahawanan digital (KD) dilihat sebagai penciptaan dan penggunaan teknologi baru dalam mentransformasikan perniagaan sedia ada yang mendorong dalam meningkatkan operasi perniagaan serta mencipta model perniagaan baru yang berdaya saing (European Commission, 2015). KD merupakan perniagaan dalam persekitaran perniagaan tradisional yang didigitalkan berdasarkan penggunaan media digital dan teknologi (Nambisan, 2017; ). Justeru, menurut Sahut et al. (2019) KD merupakan satu pertambahan dan penyatuan usaha tradisional dengan teknologi terkini untuk mewujudkan perniagaan digital (Le Dinh et al., 2018). Menurut Valigursky et al. (2021) KD merupakan transformasi aktiviti keusahawanan dengan memperkenalkan inovasi serta meningkatkan daya saing di pasaran negara dan dunia. Musbri (2011) turut mengatakan bahawa keusahawanan digital merupakan medium transaksi perniagaan atas talian menggunakan kemudahan infrastruktur teknologi yang berinovasi.

Menurut Nizam et al. (2013) KD bagi pelajar institusi pengajian tinggi dibahagikan kepada beberapa kategori seperti droship, rangkaian sosial, pemasaran e-mel, afiliasi dan forum pemasaran. Platform media sosial menghasilkan peluang tambahan untuk usahawan serta organisasi lain juga membuat aktiviti mereka lebih terkawal (Rippa \& Secundo, 2019). Menurut Von Briel et al. (2018) infrastruktur digital dan teknologi merupakan sokongan luaran bagi mencipta usaha baru dalam aktiviti bidang keusahawanan serta transformasi dalam perniagaan dengan mengembangkan serta mengeksperimenkan teknologi digital baru untuk meningkatkan pemasaran KD (Zhao \& Collier, 2016).

\section{Pemilihan Kerjaya Keusahawanan}

Kajian Persekitaran dan tingkah laku pelajar universiti mendorong pemilihan kerjaya keusahawanan (Norasmah et al., 2012). Kemahiran penggunaan teknologi dalam kalangan pelajar berupaya mendorong mereka menjadi usahawan digital (Nor Asiah et al., 2018). Pengalaman, pembelajaran kursus universiti serta penerimaan anugerah merupakan faktor luaran yang menggalakkan pelajar menyertai bidang keusahawanan sebagai kerjaya (Rummel et al., 2019). Program e-Usahawan merupakan inisiatif yang diberi penekanan dalam pengajaran dan pembelajaran kurikulum pelajar politeknik dalam melahirkan lebih ramai pelajar menyertai bidang keusahawanan sebagai kerjaya (Zainudin et al., 2020). Justeru, 
dapatan ini juga disokong kajian Rodriguez dan Lieber (2020) membuktikan bahawa pelajar yang mempunyai pemikiran keusahawanan dan kritis lebih tertumpu kepada kerjaya keusahawanan digital.

\section{Literasi Media Sosial}

Literasi merupakan keupayaan individu menguasai kemahiran serta strategi daya pemikiran kritis dan kreatif (Koo et al., 2010). Media Sosial berperanan mempengaruhi individu dalam membuat keputusan pembelian dan urusan atas talian (Naeem, 2021). Laman sosial adalah alat yang baik untuk berinteraksi dengan pelajar kerana mereka sangat biasa, menggunakan laman web dengan kerap sepanjang kehidupan seharian (Lewis \& Molyneux. 2019). Media sosial sebagai platform untuk memperlihatkan bakat golongan belia dan membangunkan serta mereka bentuk permulaan dalam bidang yang mereka minati (George, 2020). Literasi media sosial mendorong individu untuk mencari maklumat perniagaan yang memberi kesan besar kepada peningkatan prestasi serta inovasi kepada perusahaan (Alarcón-del-Amo et al., 2018 ; Olanrewaju et al., 2020).

Omar et al. (2019) penyertaan digital merupakan kemajuan yang digunakan untuk mempromosikan perniagaan ke peringkat global. Dalam pada itu, kajian yang dilakukan oleh Suriantie dan Nor Aishah (2017), media sosial digunakan bertujuan untuk memperkenalkan serta mempromosikan perniagaan batik dapat meningkatkan hasil dan produktiviti jualan. Kajian Brooks et al. (2014) menunjukkan bahawa pesaing telah memanfaatkan platform media sosial dalam memasarkan maklumat perniagaan. Seperti yang dilaporkan Lister (2018) lebih dari 50 juta perniagaan menggunakan halaman perniagaan di media sosial dengan menggunakan iklan langsung. Pickard-Whitehead (2018), trend yang sama dilihat bahawa 50 peratus pengguna telah mengikuti halaman perniagaan di platform media sosial seperti di Instagram. Platform media sosial menghasilkan peluang tambahan untuk usahawan, dan organisasi lain juga membuat aktiviti mereka lebih terkawal (Rippa \& Secundo, 2019).

Menurut Kraus et al. (2019) isu berkaitan perniagaan digital terus berubah dari semasa ke semasa. Kajian teknologi media sosial seperti Facebook banyak diguna pakai oleh pelajar politeknik bertujuan untuk mendapatkan hiburan (Wan Norina et al., 2015). Media sosial menyumbang impak negatif apabila terdapat kelemahan dalam pengurusan media sosial serta perlu ditangani dengan segera bagi mengelakkan berlaku situasi yang lebih buruk (Manap et al., 2016). Seterusnya, masalah pengurusan pekerja terganggu, kurang keberkesanan dalam penjenamaan serta masalah dalam komunikasi (Abdul \& Mwasimba, 2017).

Golongan pelajar hanya membudayakan media sosial sebagai ruang untuk berkongsi gambar dan video (Khalid et al., 2018) dan sebanyak 96\% golongan belia menggunakan media sosial untuk tujuan berkongsi gambar dan video dan hanya $8 \%$ untuk tujuan mempromosikan aktiviti perniagaan (Kulkarni, 2019). Perkara ini menunjukkan bahawa golongan pelajar memerlukan pendedahan terhadap pengetahuan dan kemahiran dalam menganalisis data dan memupuk kemampuan menilai maklumat dalam media sosial (Rani \& Padmalosani, 2019).

\section{Tujuan Kajian}

Tujuan kajian ini dijalankan bertujuan untuk mengkaji elemen media sosial yang dapat menyumbang terhadap pemilihan kerjaya keusahawanan digital dalam kalangan pelajar Politeknik Sultan Salahuddin Abdul Aziz Shah (PSA). Kajian ini membangkitkan persoalan-persoalan seperti berikut:

i. Apakah tahap kecenderungan pemilihan kerjaya keusahawanan digital pelajar PSA?

ii. Apakah tahap literasi media sosial pelajar terhadap pemilihan kerjaya keusahawanan digital?

iii. Adakah terdapat hubungan signifikan antara literasi media sosial terhadap kecenderungan pelajar terhadap pemilihan kerjaya keusahawanan digital? 


\section{Metod Kajian}

\section{Reka Bentuk dan Sampel Kajian}

Kajian ini menggunakan reka bentuk kajian tinjauan dengan instrumen soal selidik. Populasi kajian melibatkan pelajar semester akhir dari Jabatan Perdagangan Politeknik Sultan Salahuddin Abdul Aziz Shah (PSA). Jumlah populasi 359 orang pelajar ambilan sesi Jun 2017 (Jabatan Pendidikan Politeknik, 2017) yang terdiri daripada program Diploma Insurans, Pemasaran, Pengurusan Perniagaan dan Perniagaan Antarabangsa di Jabatan Perdagangan PSA.

Berdasarkan Jadual persampelan Krejcie dan Morgan (1970). seramai 186 orang dipilih sebagai sampel. Kajian ini menggunakan kaedah persampelan rawak mudah di mana kaedah ini memberi peluang yang sama kepada semua pelajar di Jabatan Perdagangan PSA untuk menjawab soalan borong soal selidik. Borang soal selidik diedarkan menggunakan Google form kepada pelajar serta borang soal selidik yang lengkap dianalisis menggunakan Statistical Package for Social Science (SPSS) versi 26.

\section{Instrumen}

Soal selidik kajian ini terdiri daripada dua bahagian. Bahagian A mengandungi 4 item mengenai kecenderungan keusahawanan digital dan bahagian B mengandungi 16 item yang menilai berkaitan literasi media sosial responden serta diperincikan kepada dua konstruk iaitu kemahiran mereka bentuk (9 item) dan kemahiran mengurus ( 7 item). Instrumen bagi kecenderungan keusahawanan ini diadaptasi dari kajian Fardeana (2020) manakala pemboleh ubah literasi media sosial diadaptasi dan diubahsuai daripada kajian (Noor Hafizah \& Rosnaimah, 2017). Responden menggunakan lima mata Skala Likert (1=Sangat Tidak Setuju kepada 5=Sangat Setuju) untuk menunjukkan sejauh mana setiap item menerangkannya.

\section{Kaedah Analisis Data}

Pengkaji menggunakan dua jenis penganalisisan statistik iaitu analisis deskriptif, dan analisis Korelasi Pearson. Statistik deskriptif kajian ini menggunakan skor min dan sisihan piawai bagi mengenal pasti tahap kecenderungan keusahawanan digital dan tahap literasi media sosial Penilaian skor min bagi pemboleh ubah adalah menggunakan skala seperti dalam jadual 1.

Jadual 1: Interpretasi skor min

\begin{tabular}{cc}
\hline Skor min & Interpretasi \\
\hline $1.00-2.00$ & Sederhana Rendah \\
$2.01-3.00$ & Rendah \\
$3.01-4.00$ & Sederhana Tinggi \\
$4.01-5.00$ & Tinggi \\
\hline
\end{tabular}

Sumber: Nunnally dan Bernstein (1994)

Analisis ujian Korelasi Pearson digunakan dalam kajian ini untuk menguji hubungan antara literasi media sosial terhadap kecenderungan pemilihan kerjaya keusahawanan digital pelajar PSA. Ujian ini dijalankan untuk membuktikan secara empirikal melalui kaedah statistik sama ada wujud hubungan dan bagaimana bentuk hubungan yang wujud sama ada hubungan secara positif atau sebaliknya. Kekuatan hubungan antara pemboleh ubah diinterpretasikan menggunakan kaedah Schober dan Schwarte (2018) seperti di jadual 2.

Jadual 2: Nilai Korelasi

\begin{tabular}{cc}
\hline Nilai Korelasi Sampel $(\mathbf{r})$ & Interpretasi \\
\hline $\mathbf{0 . 0 0}-\mathbf{0 . 1 0}$ & Tidak ada korelasi \\
\hline
\end{tabular}


DOI: https://doi.org/10.47405/mjssh.v6i2.651

\begin{tabular}{cc}
\hline $\mathbf{0 . 1 0}-\mathbf{0 . 3 9}$ & Korelasi lemah \\
$\mathbf{0 . 4 0}-\mathbf{0 . 6 9}$ & Korelasi sederhana \\
$\mathbf{0 . 7 0}-\mathbf{0 . 8 9}$ & Korelasi kuat \\
$\mathbf{0 . 9 0}-\mathbf{1 . 0 0}$ & Korelasi sangat kuat \\
\hline Sumber: Schober dan Schwarte $(2018)$ &
\end{tabular}

Sumber: Schober dan Schwarte (2018)

Instrumen kajian telah melalui proses kesahan kandungan dinilai dengan menggunakan SPSS serta telah melalui kajian rintis kepada 30 orang pelajar PSA. Kesahan instrumen menunjukkan elemen literasi media sosial adalah antara 0.68 sehingga 0.86 dan kecenderungan pemilihan kerjaya keusahawanan digital antara 0.76 sehingga 0.83. Dapatan kajian rintis menunjukkan nilai Crobach's Alpha, tahap kebolehpercayaan bagi tahap literasi media sosial telah diperincikan kepada konstruk mereka bentuk media sosial yang diperoleh adalah sebanyak 0.89 dan konstruk mengurus media sosial adalah 0.91 . Seterusnya, Cronbach's Alpha bagi kecenderungan keusahawanan digital juga menunjukkan instrumen pada tahap yang baik iaitu sebanyak 0.87. Menurut Kline (2011) instrumen adalah baik serta relevan untuk digunakan sekiranya nilai alpha melebihi atau sama 0.80 .

\section{Dapatan dan Perbincangan Kajian}

Kajian ini telah melibatkan 187 orang pelajar semester akhir di Fakulti Perdagangan seramai 65 orang pelajar lelaki dan 122 orang pelajar perempuan. Responden yang paling ramai adalah Melayu seramai 143 orang, diikuti responden Cina seramai 23 orang dan India seramai 21 orang,

\section{Tahap Kecenderungan Keusahawanan Digital}

Dapatan kajian dianalisis menggunakan kaedah statistik deskriptif dengan melihat skor min bagi menjawab persoalan kajian, "Apakah tahap kecenderungan keusahawanan digital pelajar PSA?". Kecenderungan keusahawanan digital pelajar PSA ditunjukkan pada jadual 3. Secara keseluruhan, nilai $\min =3.74$ dan nilai sisihan piawai 0.80 menunjukkan tahap kecenderungan keusahawanan digital pelajar berada pada tahap sederhana tinggi. Hal ini dapat dibuktikan dengan keempat-empat item mendapat persetujuan melebihi 50 peratus responden.

Jadual 3: Tahap Kecenderungan Keusahawanan Digital Pelajar PSA

\begin{tabular}{|c|c|c|c|c|c|c|c|c|}
\hline \multirow[t]{3}{*}{ Item } & \multicolumn{6}{|c|}{ Skala } & \multirow{3}{*}{\multicolumn{2}{|c|}{ Min }} \\
\hline & \multicolumn{2}{|c|}{ TS } & \multicolumn{2}{|c|}{ KS } & \multicolumn{2}{|c|}{$\mathbf{S}$} & & \\
\hline & $\mathrm{n}$ & $\%$ & $\mathrm{n}$ & $\%$ & $\mathbf{N}$ & $\%$ & & \\
\hline $\begin{array}{l}\text { KK1 untuk menjadi usahawan } \\
\text { digital saya sanggup melakukan } \\
\text { apa sahaja. }\end{array}$ & 29 & 15.5 & 45 & 24.1 & 113 & 60.4 & 3.74 & .80 \\
\hline $\begin{array}{l}\text { KK2 matlamat profesional saya } \\
\text { untuk menjadi seorang } \\
\text { usahawan. }\end{array}$ & 20 & 10.7 & 57 & 30.5 & 110 & 57.7 & & \\
\hline $\begin{array}{l}\text { KK3 saya memilih untuk } \\
\text { berniaga daripada makan gaji di } \\
\text { Syarikat. }\end{array}$ & 20 & 10.7 & 44 & 23.5 & 123 & 65.7 & & \\
\hline $\begin{array}{l}\text { KK4 saya akan berusaha } \\
\text { membuka firma keusahawanan } \\
\text { sendiri. }\end{array}$ & 25 & 13.5 & 41 & 21.9 & 121 & 64.8 & & \\
\hline
\end{tabular}

Analisis lebih jelas menunjukkan item KK1 dan KK2 mendapat persetujuan yang tertinggi. Item KK1 sebanyak 60.3 peratus pelajar bersetuju dengan penyataan untuk menjadi usahawan digital mereka sanggup melakukan apa sahaja dan item KK2 sebanyak 67.7 peratus responden telah menyatakan setuju dengan penyataan dalam memilih untuk menceburi bidang keusahawanan digital daripada makan gaji. Seterusnya, item KK3 dan KK4 sebanyak 65.7 peratus dan 64.8 peratus pelajar menyatakan setuju untuk 
membuka perniagaan sendiri daripada makan gaji di mana-mana Syarikat. Faradillah et al. (2019) berpendapat bahawa kecenderungan keusahawanan digital individu perlu mempunyai kemampuan diri untuk merancang kewangan, menetapkan komitmen, serta berkemahiran untuk mengurus organisasi dan bersedia menguruskan waktu untuk menjadi seorang usahawan.

Item KK1 menunjukkan peratusan pelajar yang tidak setuju dengan penyataan "untuk menjadi usahawan digital saya sanggup melakukan apa sahaja". Hal ini membuktikan bahawa masih terdapat pelajar politeknik PSA masih tidak mencapai tahap keinginan yang tinggi terhadap pemilihan bidang keusahawanan digital sebagai kerjaya selepas tamat pengajian di PSA. Selari dapatan Abd Rahman et al. (2015) untuk menjadi usahawan individu perlu mempunyai tahap kompetensi usahawan yang tinggi.

\section{Tahap Literasi Media Sosial}

Dapatan kajian dianalisis menggunakan kaedah statistik deskriptif skor min dan sisihan piawai bagi menjawab persoalan kajian kedua iaitu "Apakah tahap literasi media sosial pelajar terhadap pemilihan kerjaya keusahawanan digital?". Secara keseluruhannya, tahap literasi media sosial pelajar PS A berada pada tahap sederhana tinggi $(\min =3.72$, S.P=0.77)

Jadual 4 menunjukkan skor min bagi kedua-dua konstruk adalah pada tahap sederhana tinggi iaitu konstruk kemahiran mereka bentuk (min=3.68, $\mathrm{S} . \mathrm{P}=.81$ ) dan konstruk kemahiran mengurus ( $\min =3.76$, $\mathrm{S} . \mathrm{P}=.74$ ). Konstruk mereka bentuk dapat dilihat dari item LM3 dan LM9 yang menyumbang peratusan pelajar mahir yang tinggi. LM3 sebanyak 64.1 peratus pelajar mahir dengan penyataan "Saya mahir membina laman perniagaan di Media Sosial (Facebook, Instagram, Youtube, Twitter, Telegram)". LM9 sebanyak 64.7 peratus pelajar mahir dalam mengemas kini laman Facebook secara konsisten dan berjadual. Dapatan ini selari dengan Misirlis dan Vlachopoulou (2018) media sosial merupakan platform yang paling menguntungkan untuk mengiklankan barangan dan perkhidmatan. Justeru, sosial media digital merupakan kejayaan individu untuk memajukan perniagaan di peringkat antarabangsa (Olanrewaju et al., 2020).

Manakala, masih terdapat pelajar yang tidak mahir dalam tahap literasi media sosial. Perkara ini dapat dilihat pada konstruk kemahiran mereka bentuk terdapat 2 dari 9 item yang dikaji mempunyai jumlah pelajar yang tidak mahir tinggi iaitu item LM1 dan LM2. Item LM1 sebanyak 18.7 peratus orang pelajar tidak mahir dengan penyataan "Saya mahir membina Laman Web/ Website/ Blog/ Browser untuk perniagaan menggunakan web builder (wix, weebly etc)". Item LM2 sebanyak 15.5 peratus pelajar menyatakan bahawa mereka tidak mahir dalam mengendalikan akaun Shopee untuk perniagaan. Seterusnya, konstruk mengurus item LM14 menunjukkan sejumlah 16.1 peratus pelajar tidak mahir dalam memahami isi kandungan laman web yang dibina bagi urusan perniagaan yang dijalankan. Justeru itu, masih terdapat perkara yang perlu diberi perhatian oleh pensyarah dan pelajar berkaitan literasi media sosial untuk membangunkan laman web serta pelajar perlu menguasai penggunaan laman web untuk meningkatkan perniagaan digital. Kemudahan teknologi laman web merupakan kelebihan individu untuk menjalankan perniagaan online (Iklima Husna \& Pei Sung, 2020). 
Jadual 4: Tahap Literasi Media Sosial Pelajar PSA

\begin{tabular}{|c|c|c|c|c|c|c|c|c|c|c|}
\hline \multirow[t]{3}{*}{ Konstruk } & \multirow[t]{3}{*}{ Item } & \multicolumn{6}{|c|}{ Skala } & \multirow{3}{*}{$\begin{array}{c}\text { Mi } \\
\mathbf{n}\end{array}$} & \multirow{3}{*}{$\begin{array}{l}\mathbf{S} \\
\mathbf{P}\end{array}$} & \multirow{3}{*}{$\begin{array}{c}\text { Interpretasi } \\
\text { Tahap }\end{array}$} \\
\hline & & \multicolumn{2}{|c|}{ TM } & \multicolumn{2}{|c|}{ SM } & \multicolumn{2}{|c|}{ M } & & & \\
\hline & & $\mathrm{N}$ & $\%$ & $\mathrm{n}$ & $\%$ & $\mathrm{~N}$ & $\%$ & & & \\
\hline \multirow{26}{*}{$\begin{array}{l}\text { Merekabe } \\
\text { ntuk }\end{array}$} & LM1 Saya mahir membina Laman Web/ & 3 & 1 & 5 & 2 & 9 & 5 & & & \\
\hline & Website/ Blog/ Browser untuk & 5 & 8. & 3 & 7. & 9 & 2. & & & \\
\hline & $\begin{array}{l}\text { perniagaan menggunakan web builder } \\
\text { (wix, weebly etc). }\end{array}$ & & 7 & & 9 & & 9 & & & \\
\hline & LM2 Saya mahir membangunkan dan & 2 & 1 & 4 & 2 & 1 & 6 & 3.6 & .8 & Sederhana \\
\hline & mengendali akaun shopee untuk & 9 & 5. & 5 & 4. & 1 & 0 . & 8 & $\mathbf{1}$ & \\
\hline & perniagaan. & & 5 & & 1 & 3 & 4 & & & \\
\hline & LM3 Saya mahir membina pages & 1 & 8 & 5 & 2 & 1 & 6 & & & \\
\hline & perniagaan di Media Sosial & 5 & & 2 & 7. & 2 & 4. & & & \\
\hline & $\begin{array}{l}\text { (Facebook,Instagram,Youtube,Twitter, } T \\
\text { elegram) }\end{array}$ & & & & 8 & 0 & 1 & & & Tinggi \\
\hline & MS4 Saya mahir menggunakan & 2 & 1 & 5 & 2 & 1 & 6 & & & \\
\hline & kemudahan Facebook/Instagram & 3 & 2. & 1 & 7. & 1 & 0. & & & \\
\hline & $\begin{array}{l}\text { Advertisement untuk memasarkan } \\
\text { produk. }\end{array}$ & & 3 & & 3 & 3 & 4 & & & \\
\hline & LM5 Saya mahir dalam mengedit & 1 & 8 & 5 & 2 & 1 & 6 & & & \\
\hline & gambar menggunakan telefon bimbit. & 5 & & 5 & 9. & 1 & 2. & & & \\
\hline & & & & & 4 & 7 & 6 & & & \\
\hline & LM6 Mahir membina link building dan & 2 & 1 & 6 & 3 & 1 & 5 & & & \\
\hline & menggunakan perkataan yang sesuai & 0 & 0 . & 7 & 5. & 0 & 3. & & & \\
\hline & $\begin{array}{l}\text { serta mudah diterima pengguna media } \\
\text { sosial. }\end{array}$ & & 7 & & 8 & 0 & 5 & & & \\
\hline & LM7 Mahir mengedit kandungan video & 2 & 1 & 5 & 3 & 1 & 5 & & & \\
\hline & di Youtube & 0 & 0 . & 7 & 0 . & 1 & 8. & & & \\
\hline & & & 7 & & 5 & 0 & 8 & & & \\
\hline & LM8 Mahir dengan menggunakan & 1 & 1 & 5 & 2 & 1 & 6 & & & \\
\hline & aplikasi editing di media sosial & 9 & $\begin{array}{l}0 . \\
1\end{array}$ & 4 & $\begin{array}{l}8 . \\
9\end{array}$ & $\begin{array}{l}1 \\
4\end{array}$ & 1 & & & \\
\hline & LM9 Saya mengemaskini Facebook & 1 & 7. & 5 & 2 & 1 & 6 & & & \\
\hline & Pages serta melakukannya secara & 4 & 5 & 2 & 7. & 2 & 4. & & & \\
\hline & konsisten \& berjadual & & & & 8 & 1 & 7 & & & \\
\hline \multirow[t]{21}{*}{ Mengurus } & LM10 Saya mengemaskini Instagram & 1 & 7. & 5 & 3 & 1 & 6 & & & \\
\hline & Account serta melakukannya secara & 4 & 5 & 7 & 0 . & 1 & 2. & & & \\
\hline & konsisten \& berjadual & & & & 5 & 6 & 6 & & & \\
\hline & LM1 1 Saya mahir dengan teknik & 1 & 9. & 4 & 2 & 1 & 6 & 3.7 & .7 & Sederhana \\
\hline & copywriting & 7 & 1 & 6 & 4. & 2 & 6. & 6 & 6 & \\
\hline & & & & & 6 & 4 & 3 & & & \\
\hline & LM12 Saya mahir dengan teknik & 1 & 7. & 5 & 3 & 1 & 6 & & & Tinggi \\
\hline & memuat naik/ turun dokumen dan video & 4 & 4 & 9 & 1. & 1 & 0. & & & \\
\hline & menggunakan teknologi. & & & & 6 & 4 & 9 & & & \\
\hline & LM13 Saya mempunyai kemahiran & 1 & 1 & 5 & 3 & 1 & 6 & & & \\
\hline & dalam berkomunikasi dengan pelanggan & 7 & 6. & 7 & 0 . & 1 & 0. & & & \\
\hline & $\begin{array}{l}\text { menggunakan aplikasi whatsapps, email } \\
\text { dan telegram. }\end{array}$ & & 1 & & 5 & 3 & 4 & & & \\
\hline & LM14 Saya mahir dalam memahami & 3 & 1 & 5 & 2 & 1 & 5 & & & \\
\hline & kandungan laman web yang dibina. & 0 & 6. & 5 & 9. & 0 & 4. & & & \\
\hline & & & 1 & & 4 & 2 & 5 & & & \\
\hline & LM15 Menggunakan google playstore@ & 2 & 1 & 4 & 2 & 1 & 6 & & & \\
\hline & apps store untuk install tool editing & 0 & 0 . & 9 & 6. & 1 & 2. & & & \\
\hline & & & 7 & & 2 & 8 & 3 & & & \\
\hline & LM16 Saya mempunyai kemahiran asas & 1 & 7. & 5 & 2 & 1 & 6 & & & \\
\hline & fotografi \& pengeditan gambar & 4 & 5 & 0 & 6. & 2 & 5. & & & \\
\hline & mnggunakan trend teknologi terkini. & & & & 7 & 3 & 7 & & & \\
\hline
\end{tabular}




\section{Hubungan Literasi Media Sosial Terhadap Pemilihan Kerjaya Keusahawanan Digital}

Hasil analisis Korelasi Pearson jadual 5 menunjukkan bahawa terdapat hubungan signifikan antara literasi media sosial terhadap pemilihan kerjaya keusahawanan digital dalam kalangan pelajar PSA. Secara perinciannya, wujud hubungan dengan korelasi sederhana bagi kedua-dua konstruk iaitu kemahiran mereka bentuk $(r=0.507, \mathrm{p}<0.05)$ dan kemahiran mengurus $(r=.465, \mathrm{p}<0.05)$. Justeru, wujud hubungan positif signifikan dengan korelasi sederhana antara literasi media sosial dengan kecenderungan pemilihan kerjaya keusahawanan digital. Dapatan ini selari dengan Nor Asiah et al. (2018) yang menyatakan bahawa pengaruh digital dapat meningkatkan kemahuan pelajar menyertai aktiviti bidang keusahawanan. Dalam konteks ini, penggunaan teknologi media sosial dapat mendorong individu memilih kerjaya keusahawanan digital (Oppong et al., 2020).

Jadual 5 :Ujian Korelasi Pearson

\begin{tabular}{lcc}
\hline Pemboleh ubah & Kecenderungan keusahawanan digital \\
\hline & $\mathrm{r}$ & $\mathrm{P}$ \\
Mereka bentuk media sosial & .507 & .000 \\
Mengurus media sosial & .465 & .000 \\
\hline
\end{tabular}

Signifikan pada nilai $\mathrm{p}<0.05$

Justeru, pelajar PSA masih belum mencapai tahap kemahiran mereka bentuk serta mengurus media sosial yang tinggi untuk menjadikan aktiviti bidang keusahawanan digital sebagai kerjaya. Terdapat responden kajian ini tidak terfikir untuk menjadikan aktiviti bidang keusahawanan digital sebagai pemilihan kerjaya di masa hadapan. Ini kerana, pelajar masih belum bersedia untuk menanggung risiko menjadi usahawan (Nur Fardeana et al., 2020).

\section{Kesimpulan}

Keusahawanan digital dilihat mempunyai potensi besar kepada pelajar PSA dalam mencipta kerjaya pada masa kini. Tujuan utama penyelidikan ini adalah untuk memahami bagaimana literasi media sosial membantu serta mengubah minat pelajar PSA terhadap pemilihan kerjaya keusahawanan digital.

Seterusnya, kajian ini diharapkan dapat membantu pelajar serta pihak politeknik dalam mempergiat aktiviti keusahawanan digital dengan lebih berinovasi agar ia setanding dengan perniagaan digital yang telah mencipta nama dalam dunia perniagaan digital seperti Shopee, Amazon, Fashionvalet dan sebagainya. Kesimpulannya, hubungan antara tahap literasi media sosial terhadap pemilihan kerjaya keusahawanan digital berada pada tahap sederhana tinggi dalam mempengaruhi pelajar PSA. Menurut Fardeana et al. (2020) keputusan dalam menceburi bidang keusahawanan digital adalah disebabkan kesungguhan dalam melaksanakan aktiviti bidang keusahawanan digital. Namun masih terdapat beberapa elemen yang perlu dititikberatkan agar kerjaya keusahawanan digital menjadi pilihan utama bukan sahaja kepada golongan pelajar politeknik akan tetapi universiti awam dan swasta yang lain.

Pihak Politeknik dan universiti boleh menekankan pembelajaran dan perniagaan dalam membentuk laman web untuk mempromosikan serta menjalankan urusan jual beli secara bersistem. Selain itu, pihak politeknik, universiti awam dan swasta menggalakkan lebih ramai pelajar menjalankan perniagaan di media sosial seperti Facebook dan Instagram. Seiring dengan Pelan Tindakan Keusahawanan Institusi Pendidikan Tinggi 2021-2025 serta garis panduan Kementerian Pengajian Tinggi (KPT) dalam memperkasakan agenda keusahawanan yang berteraskan penguasaan teknologi dalam kalangan pelajarpelajar di universiti awam, kolej komuniti dan politeknik.

Kajian ini mencadangkan agar kajian seterusnya dapat dilakukan dengan mengkaji beberapa faktor yang dapat mempengaruhi pemilihan kerjaya keusahawanan digital pelajar tahun akhir di politeknik dan universiti. Seterusnya, golongan pelajar dapat memanfaatkan dengan mencipta lebih banyak peluang pekerjaan. Selain itu, pihak politeknik juga perlu mengenal pasti pelajar yang berpotensi untuk 
DOI: https://doi.org/10.47405/mjssh.v6i2.651

meneruskan aktiviti yang melibatkan bidang keusahawanan digital. Serta dapat memperkukuhkan lagi visi negara, kementerian serta institusi dalam menjadikan bidang keusahawanan digital sebagai bidang yang mampu mencipta peluang pekerjaan menjelang tahun 2030.

\section{Rujukan}

Abd Rahman, S. S., Muhammad Sabri, M. F. \& Nadzri, S. (2015). Kompetensi Keusahawanan Diri Dalam kalangan mahasiswa yang mengambil kursus Keusahawanan Di Universiti. Proceeding of the 2nd International Conference on Management and Muamalah 2015 (2ndICoMM) 2015(November): 372-384. Retrieved from http://www.kuis.edu.my/icomm/2nd/download/IC 034.pdf

Ahmad Fkrudin, M. Y. \& Wan Norina, W. H. (2015). Hubungan media sosial dengan penampilan akhlak pelajar politeknik malaysia (September 2018).

Alarcón-del-Amo, M. del C., Rialp-Criado, A. \& Rialp-Criado, J. (2018). Examining the impact of managerial involvement with social media on exporting firm performance. International Business Review, 27(2), 355-366. doi:10.1016/j.ibusrev.2017.09.003

Asiah, N., Juhdi, N. hasni, Hassan, R. \& Rahman, R. S. A. R. A. (2018). Mengalakkan Kecenderungan Pelajar Terhadap Keusahawanan Melalui Literasi Digital, Penggunaan ICT dan Kecekapan Kendiri Dalam Kalangan Pelajar Universiti ( Encouraging Student to Entrepreneurship through Digital Literacy, ICT Usage and Self-Efficacy amon. Jurnal Personalia Pelajar, 21(1), 43-53.

Brooks, G., Heffner, A. \& Henderson, D. (2014). A SWOT Analysis Of Competitive Knowledge From Social Media For A Small Start-Up Business. Review of Business Information Systems (RBIS), 18(1), 23-34. doi:10.19030/rbis.v18i1.8540

Dwivedi, Y. K., Hughes, D. L., Coombs, C., Constantiou, I., Duan, Y., Edwards, J. S., Gupta, B., et al. (2020). Impact of COVID-19 pandemic on information management research and practice: Transforming education, work and life. International Journal of Information Management, 7 , 102211. doi:10.1016/j.ijinfomgt.2020.102211

Faradillah Iqmar, O., Samsudin, A. R. \& Husna, A. D. (2019). Analisis Pola Penyertaan Digital ICT dan Transformasi Keusahawanan (Analysis of Digital Inclusion Pattern and Entreprenuership Transformation). Jurnal Komunikasi: Malaysian Journal of Communication, 35(2), 314-330. doi:10.17576/jkmjc-2019-3502-19

Fardeana, U. R. (2020). Tahap Personaliti Big Six dan Hubungannya dengan Kecenderungan Keusahawanan Digital dalam Kalangan Pelajar Kolej Komuniti, 45(1), 101-110.

Finkle, T. A. (n.d.). Technology entrepreneurship : Creating your own online business. Journal of Technology Research, 8, 1-13.

Iklima Husna, A. R. \& Pei Sung, P. (2020). Factors Influencing Students Tendency in Doing Online Business. Advanced International Journal of Business, Entrepreneurship and SMEs, 2(3), 01-11. doi:10.35631/aijbes.23001

Le Dinh, T., Vu, M. C. \& Ayayi, A. (2018). Towards a living lab for promoting the digital entrepreneurship process. International Journal of Entrepreneurship, 22(1), 1-17.

Lewis, S. \& Molyneux, L. (2019). Social Media and Journalism: 10 Years Later, Untangling Key Assumptions. Proceedings of the 52nd Hawaii International Conference on System Sciences 6: 2580-2589. doi:10.24251/hicss.2019.311

Misirlis, N. \& Vlachopoulou, M. (2018). Social media metrics and analytics in marketing - S3M: A mapping literature review. International Journal of Information Management, 38(1), 270-276. doi:10.1016/j.ijinfomgt.2017.10.005

Muhammad, N., Wan Mohd Fauzan, W. N. S. \& Zainon, R. (2018). Kesediaan Golongan Belia Dalam Bidang Perniagaan Atas Talian Di Pantai Dalam, Kuala Lumpur. Journal ofBusiness Innovation, 3(2), 52-60.

Mustaffa, N., Wan Amizah Wan mahmud, Fauziah Ahmad, Maizatul Haizan Mahbob Mohd. Helmi Abd. (2013). Kebergantungan Internet Dan Aktiviti, 29(1), 199-212.

Naeem, M. (2021). Do social media platforms develop consumer panic buying during the fear of Covid19 pandemic. Journal of Retailing and Consumer Services, 58, 102226. doi:10.1016/j.jretconser.2020.102226 
Nambisan, S. (2017). Digital Entrepreneurship: Toward a Digital Technology Perspective of Entrepreneurship. Entrepreneurship: Theory and Practice, 41(6), 1029-1055. doi:10.1111/etap.12254

Noor Hafizah, H. \& Rosnaimah, M. Y. (2017). Tahap Literasi Keusahawanan Digital Dalam Kalangan Pelajar Yang Mengikuti Kursus DPB5063 Pembangunan Keusahawanan Digital.

Norasmah, O., Nor Hafiza, O., Tin, P. B. \& Rahma, I. (2012). Impak Globalisasi dan Tingkah Laku Pemilihan Kerjaya. Prosiding Perkem Vii Jilid 1: 435-445.

Olanrewaju, A. S. T., Hossain, M. A., Whiteside, N. \& Mercieca, P. (2020). Social media and entrepreneurship research: A literature review. International Journal of Information Management, 50, 90-110. doi:10.1016/j.ijinfomgt.2019.05.011

Oppong, G. Y. S., Singh, S. \& Kujur, F. (2020). Potential of digital technologies in academic entrepreneurship - a study. International Journal of Entrepreneurial Behaviour and Research. doi:10.1108/IJEBR-06-2019-0401

Rippa, P. \& Secundo, G. (2019). Digital academic entrepreneurship: The potential of digital technologies on academic entrepreneurship. Technological Forecasting and Social Change 146, 900-911. doi:10.1016/j.techfore.2018.07.013

Rodriguez, S. \& Lieber, H. (2020). Relationship Between Entrepreneurship Education, Entrepreneurial Mindset, and Career Readiness in Secondary Students. Journal of Experiential Education, 43(3), 277-298. doi:10.1177/1053825920919462

Rummel, S., Akkermans, J., Blokker, R. \& Van Gelderen, M. (2019). Shocks and entrepreneurship: a study of career shocks among newly graduated entrepreneurs. Career Development International. doi:10.1108/CDI-11-2018-0296

Sahut, J. M., Iandoli, L. \& Teulon, F. (2019). The age of digital entrepreneurship. Small Business Economics (August). doi:10.1007/s11187-019-00260-8

Schober, P. \& Schwarte, L. A.(2018). Correlation coefficients: Appropriate use and interpretation. Anesthesia and Analgesia, 126(5), 1763-1768. doi:10.1213/ANE.0000000000002864

Valigursky, D. I., Kuzmina, T. T., Maslova, E. L., Irina O. Ryzhova, A. \& Goncharenko, V. I. (2021). Entrepreneurship at the stage of development of the digital economy. doi:10.1007/978-3-030$57831-2$

Vase.ai. (2020). Change In Consumer Purchase Behaviours (April).

Wang, W., Liang, Q., Mahto, R. V., Deng, W. \& Zhang, S. X. (2020). Entrepreneurial entry: The role of social media. Technological Forecasting and Social Change, 161. doi:10.1016/j.techfore.2020.120337

Zainudin, M. Z., Mohamad, M. \& Raja Azlan Shah, R. Y. S. (2020). Amalan Terbaik Kurikulum Keusahawanan Digital Melalui Inisiatif eUsahawan MDEC Terhadap Politeknik Malaysia (June 2019). 